Historic, Archive Document

Do not assume content reflects current scientific knowledge, policies, or practices. 



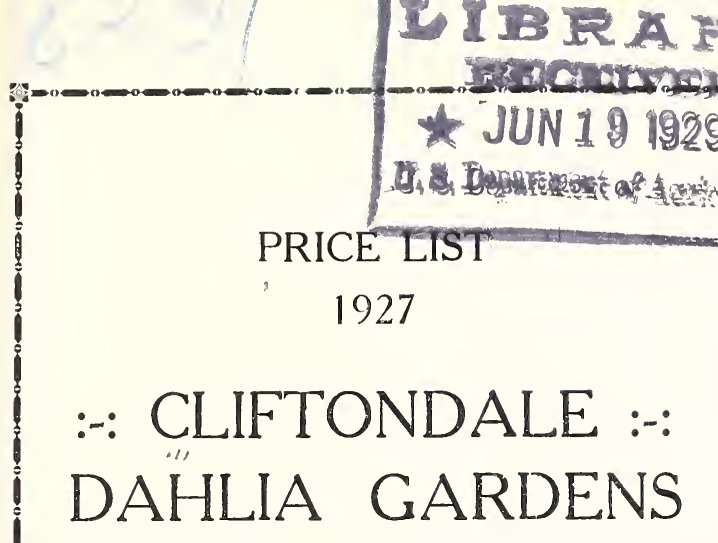

ON THE NEWBURYPORT TURNPIKE CORNER OF ESSEX STREET

\section{"Field-grown Bulbs"}

TERMS-Send remittance with order. All retail orders delivered prepaid.

GUARANTEE-All tubers in growing condition and true to name.

SHIPPING-We ship as soon as danger of freezing is past.

\section{gat}

F. C. PERKINS

99 VINE STREET

TEL. HANCOCK 0608

PAY US A VISIT

"Seeing is Believing" 


\section{GROWING THE DAHLIA}

Plant the bulbs any time between May 1st and June 21 st. Plant them about four inches deep horizontally. Sandy soil is the best for dahlias. Manure should be spread upon your land in the fall and plowed in. I have found that a mixture of cow manure and horse manure makes an excellent fertilizer. Cultivate the soil at least once a week, twice is better. When the plants begin to bud spread on a little good commercial fertilizer. Water once a week and be sure to soak the soil thoroughly as a little water on the top does more harm than good.

\section{ABBREVIATIONS}

C. Signifies Cacius; D. or Dec. Decorative; H. C. Hybrid Cactus; P. Peony; D. P. Decorátive Peony; S. Show.

AIBONITA (D.). An immense flower of a lavender or violet pink, shading to white, with a rich golden yellow at the center. The long graceful stems hold the huge blossoms high above the foliage.

AMLO (Bessie Bosion). Have you grown San Mateo, the monster bi-color? If you have, let us state, Amigo resembles it in everything but color. The flower has the same size, substance, petal formation, and long stem. Crows very tall and carries its blooms well above the foliage. But the charm about this new decorative, is its marvellous coloring, gold, illuminated with a sunset glow. The cleft or staghorn petals add much to its attraction. The center remains closed the entire season and late blossoms are often better than early ones.

ALI BABA (D.). A large full and very deep flower on strong stem. Long, curly, waving petals. Color cardinal red, white, tipped and blended. A very free bloomer.

AMUN RA (Seal). Dec. This wonderful variety was introduced in 1922; and is declared to be the greatest Dahlia of the age. It won more first prizes last season than any other new introduction. From East, West, North, South wherever it was grown, nothing but the most enthusiastic reports have been received from the growers. The flowers are of mammouth size, borne on long stiff, stems, and the color is of that entrancing shade of glorified coppery bronze, that instantly aitracts, and holds the attention of all who see it. The plant is unusually strong and healthy. A sure producer of good tubers...........\$

A. C. LAWRENCE. Hyb. Cactus. One of the best Dahlias ever introduced, large full flower of good substance, excellent keeper when cut, color a beautiful shade of flesh pink.

ALEX WALDIE (D.). A creamy ground overlaid with delicate salmon pink. One of the most beautiful of dahlias..

ALTON H. PERKINS (F. C. Perhins). An extremely effective blossom of apricot yellow shading into a strontian yellow, splashed irregularly with carmine streaks. Fine full blossom spreading seven or eight inches with long wiry stems. Bushes from four to five feet high. Free bloomer. 
BEN WILSON, Dec. This is one of the best Dahlias we grow in our garden. It is a fine exhibition flower, also good for cutting. Color, orange red, tipped with gold........................\$

BERTHA STORY, Dec. Beautiful shade of rose pink. Very large and free bloomer.....................

BIJOU (Bessie Boston). The color is cream, but close examination will show this deepens to yellow at the center and at the tips. The petals have a peculiar curl and twist, which make a most unusually graceful and enchanting flower of a form new to us. Grows at the top of the stem like Insulinde. Flowers are large and produced with greatest freedom. The height is moderate and the foliage is the most beautiful we have ever seen. The leaves are very large and cut as fine as a fern.

BLUE BRR (Bessie Boston). An exceptional color of the deepest tone of lilac, which in certain lights has a bluish sheen. A simply huge blossom held on stems long and as stiff as bamboo. The bushes are always laden with blooms.

CONIJIE BRAE (D.). Cream, shade blush pink; the Rowers are of true decorative form and immense in size. As an exhibition fower it is hard to beat.

BLUE JAY (D.). Deep lilac, almost blue. A wonderful flower held on long stiff stems.........\$ .75

BEAU BRUMMEL. A flower of royal purple, which does not fade nor burn on the hottest day. Stands erect on an incomparable stem. Grows on low spreading bushes. Producers the entire season a super-abundance of very big, deep blossoms. An all around excellent Dahlia of a rare color and can be recommended for any purpose.

BABA BOTT (H. C.). A wonderful sofi pink. Flowers of huge size with good strong stems...\$ $\$ 50$

BERTRA HORNE (hyb. cac.). Golden yellow and bronze.

CAIIFORNIA ENCHANTRESS (Bessie Bosion). A monster bloom of great substance and a delightful shade of pale pink. Hybrid cactus are greatly in demand because of their size and erect stems. This has both these admirable qualities, combined with freedom in flowering. "A splendid Dahlia in every way." \$ .75

CARA FINGER. Dec. Large yellow fower, one of the very largest yellows, very much admired.

CATHERINE COOPER (D.). Large flowers, good stems, rosy lavender in color.

CHESLEY PERKINS (F. C. Perkins). A heavy full bloom on long erect stems, throwing blooms well above the foliage. Bushes five to six feet tall with extra large dark green fol:age; very free bloomer. Unique coloring with scarlet face and reverse of petals shading from lemon chrome to pale scarlet at the tips of petals. Heavy cluster of petals around center showing orange chrome coloring. Awarded "Certificate of Merit" at California Trial Gardens 1926.

DR. FLOOD (D.). Red, with small, white petals, mixed, making it a most unusual flower. 
EL GRANADA (Bessie Boston). An immense orange hybrid cactus. The color is a vivid orange, and the petals twist and interlace, showing at the tips a creamy yellow reverse. The long stem grows well out of the foliage and is absolutely stiff and faultless. The high bushes are covered with large, deep flowers with closed centres, from early until late season.

ELISE DREXLER (Bessie Boston). Hybrid cactus. A deep velvety maroon bloom of huge size, borne on top of a straight long stem. The inner petals roll very closely and form almosit a star in the center. Has always produced plentifully of attractive blooms. Prize winner.

EVELYN ADAMSON (Broomall). Exquisitely charming. The prevailing color is fawn pink becoming lighter as the flower maiures. The nower is large and perfect and the venations of the petals add to its exquisite beauty.

EDITH SLOCONBE (Slocombe) H. C. A wonderful shade of rich fuschia garnet or shaded velvet maroon, a most striking flower.

FRANR A. WALEER (Dec.). Lavender pinl......\$ .25

FAITI GARABALDI. Superb rose pink decorative. Great depth as woll as large size, and is held up straight on a long, stiff sia.l. Several splendid flowers on each bush. Begins blooming about the middle of August and continues unil the frost. Does not require heavy disbudding for immense blooms. Blossoms last nearly a week in the house.

GORGEOUS (Bessie Boston). This is the most wonderful peony we have ever seen, because it has tremendous size, great depth, stiff long stems, and will bloom freely throughout the season. Late blossoms will be as large and good as the early ones. The color is yellow, shading to bright scarles. With scarcely any disbudding it will produce ten-inch fovers on stems five feet long. Plan' grows very tall. The blossoms, because of their unusual substance, last longer when cut than the average bloom of this popular type. A grand exhibition and garden flower.

G. H. CARR. Dec. A wonderful garden and exhibition variety. Color deep purple, sometimes tipped with white. Flowers large and of good substance.

GLORY OF NEW HAVEN (Slocombe). A soft pinkish mauve, a color cuite distinctive and beautiful. Long stemmed, large blooms, excellent for cutting.

GLORIEUX (Decorative). Received American Dahlia Society's Certificate of Merit at Storrs, Conn., 1920. lis name indicates its French ancestry. It is a flower of wondrous beauty on long, strong stems. Color is golden yellow deepening to gamboge bronze in the center, each petal usually tipped white. It is a very free bloomer, and with disbudding will attain a diameter of ten inches. The flower is very full and deep, and is particularly satisfactory as a cut flower. The foliage is as wonderful as the blooms, being an olive green and very dense, forming a graceful bush, the flowers standing well above same. 
GEN. MHLES. The largest fancy Show Dahlia. Color, a clear violet-rose, siriped and spotted purple.

UEORGE WALTERS (CARTER) H. C. Always among the prize winners; lovely coloring, pinkish salmon shading to yellow base...............\$

GEE WIIIZ (BROOMALL) H. C. All that the name implies. Buff and yellow with incurved petals; a mammouth flower, long stems..

HARIAN (MURPRY) Dec. (D.). Very large, round, yellow Dahlia of good substance, good stems, and a wonderful garden flower, as it blossoms freely the entire seacon

HALLOWE'EN (D.). Buff-yellow, shaded orange-bronze. The fowers are large, and are held perfectly erect on the finest possible stems.

HELEN KELLER (BROOMALL) P. Dec. Named by request in honor of one of the world's most noted women. The color being a beautiful rich rose pink. A very large flower of splendid form.

IDA PERIINS (F. C. Pexkins). Beautiful white heavy blossom with cream colored center, excellent long stems. A very strong grower; blooms spread about eight inches with incurved petals. Bushes about five feet high. Decorative.

JUDGE ALTON B. PARKER (MAREAN) Dec. Golden buff, very large and firm; a splendid variety, that will become a grcat favorite with lovers of fine Dahlias...

JUNHOR (SEAR) Dec. An enormous flower of pure lavender. A seedling of The Millionaire, but has greacer width. A magnificent flower for exhibition and garden.

KOM-LOOR (Bessie Bosion). Maroon, and at times so. dark as to be nearly black. Perfect type of hybrid cacius, as the petals roll closely and run to a point at the tip. The flower texture has a pronounced velve'y sheen which adds greatly to its beauty. Blossoms are very large and deep, and can be grown for the largest flower in the show. Centre perfect throughout the season. Siem as stiff as a cane. Blooms abundantly at all times. The very dark green foliage on the tall growing bushes is a pleasing contrast to the rich colored blooms.

LAURINE. Deep pink, a shade darker than Dorothy Durnbaugh; the flowers are twice as large as that varieiy, and are held erect on splendid long stems; a strong grower and profuse bloomer. An extra good cut-flower, 3 ft., tubers.

LADY HELEN (STLLLMAN) H. C. (D.). A fower of blending rosy red and white; very good as a cut flower on account of its fine keeping qualities.

LAKE ERIE (STHLIMAN) Dec. (D.). The color is a clear deep lavender, while the forra is quite flat, with heavy, long, flat florets. A very unusual and beautiful Dahlia, both in color and shape, which can only be realized by seeing it...

LIBERTY BOND (D.). A blending of buf, bronze and salmon shades very hard to describe; the flowers are very large, and are held on strong stems, always holding flowers erect. 
LADY DOROTHY (D.). Large orange flower with lavender sheen; grand Dahlia for all purposes.

LE GRAND MANITOU (Charmet). White ground striped and speckled violet; blooms freely on long erect stems. One of the most popular dahlias.

MARY CURTIN (Murphy). Dec. Peony. This is one of richest colored flowers we have in our garden. Was introduced by Mr. Thos. J. Murphy of Peabody, Mass. A brilliant crimson with each petal tipped pure white, the color combination staying the same throughout the season. Flowers are large, of great substance and beauty. Splendid keeper; strong, stout stems. A very attractive variety for both exhibition and garden.

MRS. J. C. HART. Dec. A wonderful shade of red; very large, deep flower of good form; free bloomer; strong stems.

MILLIONAIRE (Stillman). One of the largest Dahlias in cultivation. The color is lavender, shading to white; the flower is perfect in form.

MRS. CARL SELBACH (Selbach). Dec. A California variety of exceptional merit, which has won first prizes throughout the country. Color: a very attractive shade of lavender pink; large blooms, perfect form, long stiff stems, well above the foliage.

MRS. ETHEL F. T. SMITH (Broomall). Hybrid, of rather broad petals of cream white shading to lemon. A gigantic bloom on a fine stem, blooms freely.

MRS. I. de VER WARNER (Marean). P. D. Without a doubt this variety represents the highest type of perfection in the modern Dahlia; and is unquestionably one of the finest varieties ever introduced. lts size is impressive, both in flowers and stems. In color, it is a deep mauve pink; some might describe it as a catlleya color. Unequalled for exhibition and for the garden.

MAYOR FITZ (D.). An extra fine variety, early and free bloomer. Color a pale gold with a light fiush of red on outer petals...........\$

MRS. K. L. FIELD (H. C.). A bright glowing scarlet distinctly tipped white, with rolled incurved petals. Its graceful flowers are held on long upright stems high above the foliage...\$

MARIPOSA (Bessie Boston). H. C. Pink suffused with lilac, an extra large flower, good grower and fine stem. An excellent exhibition variety.

N. C. 4. (P). The florets are more or less striped the whole length with yellow and white, while some are slightly clouded with yellow and tipped with light cream. The reverse side of peials is white with yellow shadings.

NICHU. The blooms are immense, of very incurved shape. Flower is held erect on a strong stall. A cheerful bloomer, which will produce at all parts of the season, a mass of clear yellow blossoms, with closed centres.......\$5.00 
OUR COUNTRY (Siillman). Dec. Tuber Plant. This wonderful dahlia is very deep, large flower of purple, heavily tipped white, entirely different in color from any in the garden....... $\$ 4.00$

POLAR STAR. Dec. A pure white of remarkable beauty. Flowers large and full; very free bloomer; good stems and extra fine for cutting.

PRIDE OF CALIFORNIA (Lohrman). This is a good red decorative for all purposes. It has size, stem and splendid keeping qualities when cut.

PAUL MICHAEL. Dec. This is a grand Dahlia in every respect. A pure gold color. Flowers are extra large; the bushes are laden with blossoms that hold their size throughout the season. A wonderful garden variety.

POLARIS. Flowers of immense size and perfect form, held above the foliage on strong stems; habit of plant is rather dwarf and strong and vigorous; a flower with every good quality. Color, pure white.

ROSA NELL (Broomall) Dec. The color is a clear bright rose; flowers are large, coming perfectily full and double until frost; good stems and habit; free bloomer and attracts immediate attention.

SHUDOW'S LAVENDER (Bessie Boston). The very large bloom is a silvery lavender slightly shading to white. In hot weather, the white will be more marked, but as the season advances will almost entirely disappear. The stem is absolutely perfect, long and stiff, and holds erect the big blossom. It will bloom constantly and freely from early to late season and never show a centre, and also has excellent keeping qualities as a cut flower. One of its most unusual features is the attractive lace-like foliage. The plant is a very tall and robust grower and it often grows to the height of eight feet. Gold medal variety.

SNOWDRIFT (Broomall). This is the best decorative white I have seen. A very deep built, immense flower, with broad, waxy, pure white petals. The bloom opens quickly, remaining perfect for over a week. It never sunburns and when the last petal drops off, it is as white as when it first opened.

SOROSIS. Dec. This is one of Mr. Murphy's introductions which has been greatly admired; we consider this the finest red decorative Dahlia on the market. A rich dark velvety red, with a fine satiny sheen. Fine for cutting and very attractive in the garden.

SUSAN COE (D.). Pleasing shade of rose pink passing to a yellow center; suffused salmon......\$1.00

THE BASHFUL GIANT (Marean). Dec. This is without a doubt the largest Dahlia ever produced. The blooms are extra large and heavy, on very strong and stout stems. The beautiful color being an apricot with golden shadings. A good keeper. Wonderful exhibition and garden variety.

THE U. S. A. (H. C.). This popular new orange colored beauty is admired by all who have seen it. Very large size, with long, twisted incurved petals, making a very attractive flower. 
UNCLE SAM (Nieachen \& Sherman). Peony. Immense flower of wonderful coloring. Orange buff at base of petals, shading to a bittersweet pink at tips, all overlaid with a beautiful golden sheen. Center petals mustard yellow, streaked with deep rose pink, and beautifully curled and twisted; reverse side of petals shaded spinel red. Blooms held erect above the foliage on stiff stems. A very attractive flower in the garden, and a grand exhibition variety.

VENUS. Dec. A beautiful variety, and much esteemed as a cut flower. It is a splendid free grower, and the flower, which is a combination of pink and white, is borne on strong stems.

WORLD'S BEST WHITE (Murphy). Dec. This wonderful large white Dahlia was introduced by Mr. Thos. J. Murphy, of Peabody, Mass. who has produced a great many fine white varieties, but this one we consider the best of all. An extra large well formed flower of great substance and depth, on long stems which hold the flowers erect. Very free bloomer; plants extra strong. A grand exhibition and garden variety.

WM. SLOCOMBE. Dec. Fine large flower, well formed, of a beautiful shade of canary yellow, shading to a deep yellow towards the center. An exceptionally fine flower, carried on long stiff stems, well above the foliage.

A wonderful all round variety................................. \$

WIZARD OF OZ (Doolittle). Dec. An immense blossom, which has won many prizes for the largest flower in the shows. The color is a pleasing shade of salmon rose shading to yellow. Stems were long and good in our garden, where it was an early and continuous bloomer.

YELLOW GEM (D.). A very attractive flower. Petals white with yellow edge. Free bloomer and beautiful garden variety.

\section{MY LOSS IS YOUR GAIN}

The frost came before all my Dahlias were tagged so I am offering high grade bulbs for the small sum of TWO DOLLARS per dozen while they last.

\section{SUPPLEMENTARY}

MRS. W. D'ARCY RYAN (Bessie Boston). A lovely autumn-tinted decorative. What color is it exactly? This is rather hard to answer, as the bushes bear blossoms of gleaming old gold and also copper-colored ones. Flowers are large and regularly formed and hold their heads up proudly on perfectly stiff stalks...........\$1.50 